\title{
In vitro Preparation and Evaluation of Sustained-Release Microcapsules of Salvianolic Acid [Retraction]
}

Wang YH, Qu T, Wang XL, Yang RP. Drug Des Devel Ther. 2021;15:1623-1631.

At the authors request, the Editor and Publisher of Drug Design, Development and Therapy wish to retract the published article. The authors informed the journal when attempting to scale up salvianolic acid microcapsule development, using the same process described in the article, they were unable to replicate the results previously reported. The previous study was based on small laboratory trials and preliminary analysis with no instability of the salvianolic acid B observed. However, during the process of scaling up the study the authors observed con- siderable instability of salvianolic acid B indicating the process design is unreliable and the findings reported previously are invalid. In addition, the authors were also unable to locate the raw data for their original study. The Editor agrees with the decision to retract the paper.

Our decision-making was informed by our policy on publishing ethics and integrity and the COPE guidelines on retraction.

The retracted article will remain online to maintain the scholarly record, but it will be digitally watermarked on each page as "Retracted".

\section{Publish your work in this journal}

Drug Design, Development and Therapy is an international, peerreviewed open-access journal that spans the spectrum of drug design and development through to clinical applications. Clinical outcomes, patient safety, and programs for the development and effective, safe, and sustained use of medicines are a feature of the journal, which has also been accepted for indexing on PubMed Central. The manuscript management system is completely online and includes a very quick and fair peer-review system, which is all easy to use. Visit http://www. dovepress.com/testimonials.php to read real quotes from published authors. 